\title{
How Does Board Structure Characteristics Affect Capital Structure Decisions? Evidence from East African Stock Markets
}

\author{
Erick Lusekelo Mwambuli ${ }^{1,2, *}$ \\ ${ }^{1}$ School of Accountancy, Dongbei University of Finance and Economics (DUFE), Dalian, \\ Peoples Republic of China \\ ${ }^{2}$ Faculty of Accounting, Banking and Finance, Institute of Finance Management (IFM), Dar \\ Es Salaam, Tanzania \\ *Correspondence: No. 5 Shaaban Robert Street, P.O BOX 3918, Dar Es Salaam, Tanzania. \\ E-mail: mwambuli@ifm.ac.tz
}

Received: December 7, 2017 Accepted: December 22, 2017 Published: February 2, 2018

doi: 10.5296/jcgr.v2i1.12599 URL: https://doi.org/10.5296/jcgr.v2i1.12599

\begin{abstract}
This research examines the board structure characteristics and its effects on capital structure decisions in developing economies, East African stock markets. To achieve the objective of this research, we used a strongly balanced panel dataset of 320 observations (i.e. a sample of 32 non-financial listed firms in East African region from 2006-2015. Measures for capital structure decisions were short term debt ratio (STDR), long term debt ratio (LTDR) and total debt ratio (TDR) as dependent variables and explanatory (independent) variable was board structure characteristics measured by researcher-constructed index consisting of 10 board structure characteristics provisions; thus the board structure characteristics index (BSCI), furthermore, the effects of control variable such as firm size (SIZ), the level of economic development (GDP) and industry dummies were also examined. The panel corrected standard errors (PCSEs) regression model was employed for board structure characteristics and capital structure decisions to analyze the data. Our results indicate a statistically significant negative effect of board structure characteristics on capital structure decisions (except on short term debt where it's insignificant) all models at 5\% significance level. Our study is very innovative in both corporate finance and accounting literature and the practical implications because our study provides a first insight of the board structure characteristics and its effects on capital structure decisions for East African stock markets context. The study recommends to securities markets regulatory authorities in East African region such as East African member states securities regulatory authority (EASRA) and their respective countries securities markets regulatory authorities to stimulates new efforts towards better board structure provisions to listed firms in the regional bloc due to its statistically significant effects on financing behavior and future research can be extended after inclusion of both listed and
\end{abstract}


unlisted firms.

Keywords: Board Structure Characteristics, Capital Structure Decisions, Panel Data, Developing Economies, East African stock markets

\section{Introduction}

A considerable number of big firms around the world have been exposed to financial distress and even bankruptcy following the financial crisis of 2007-2008 (Adams, 2012; Erkens et al., 2012, Greenglass et al., 2014). This situation arises the discussions relating to the importance of capital structure decision (CSD) and the role of board structure characteristics (BSC).According to Abor and Biekpe (2007), the CSD can affect the operational and financial performance of the firm's, and hence the survival of the firms. The choice between debt, equity and a mixture of both is very critical decision to firm's managers because this CSD will affect the value of the firm. Thus, firms with poor CSD will suffer financially or might go to bankruptcy and firms with good CSD will increase their value. During recently years, researchers have been investigating the determinants that effect CSD.Over the last two decades, the concept of board structure characteristics and corporate governance at large has been a hot debate in many scholarly papers that have been published in academic journals due to various reasons. According to Becht et al. (2004), this increase in attention as due to widespread of capitalism in today's world and privatization policies; the growth in firm size; deregulation and the capital market integration and globalization; reform of pension fund and the growth of private savings; shareholder activism; the East Asian crisis 1998 and a series of the USA scandals and corporate failures of late, e.g. WorldCom and Enron.

The East African Community (EAC) is a regional intergovernmental organization in East African region with its headquarters in Arusha, Tanzania. The EAC is a unique reginal entity that was Established through Treaty for the establishment of the East African Community that was signed in 1999 and come into force in 2000.According to Article 5(2) of the Treaty establishing the EAC, the regional bloc has four (4) major objectives; namely; (i) Formation of Customs Union, (ii) Establishment of a Common Market, (iii) Establishment of a Monetary Union and (iv) To have a political united East Africa. The EAC currently comprises of six (6) Partners States (Kenya, Tanzania, Uganda, Rwanda, Burundi and South Sudan)(Note 1) with other potential partner states indicating willingness to join the regional bloc(Note 2). The EAC is the one of the fastest growing region in the Sub-Saharan Africa with an average GDP growth of 6.2 percent in 2015 .The EAC has been the fastest growing regions in the Sub-Saharan Africa since 2005, its best performance since 1970s. Indeed, at 3.5 percent per capital GDP growth during the 2005-2013, the EAC outpaced Sub-Saharan Africa at 3.3 percent (IMF, 2014).

The role of board of directors (BOD) has become the global issues due recently financial scandals around the world and collapse major corporate entities like Enron, WorldCom, BCCI and Adelphia all these issue has shaken the investor's confidence in the financial markets and a call for a good corporate governance practice to promote transparency, 
accountability, reliability and quality of financial information which in turn will lead to investor's confidence regarding the firm and financial market at large.

However, for number of years many academicians and researchers provides substantial empirical evidence on the impact of board of directors on capital structure but prior research has focused mainly in developed and emerging economies where capital markets are active and well developed (e.g.: United Kingdom and United States of America).Our study will provides a new insight on the subject matter, our research will seeks to evaluate the effect of BSC on CSD for listed firms in East African stock markets context as a developing economy. our study is very interesting, importance and contribute a lot in corporate finance and accounting literature because of a uniqueness and special business environment features in East African regional bloc, like a single regulatory body of capital markets in the regional (i.e. the EASRA), which oversight and regulates securities/stock markets in the region, and also a remarkable and explosive economic growth that took place in the region for the past 10 good years (Effective from 2005), that make the East African regional bloc as the fastest growing region in Sub-Saharan Africa with an average GDP growth of 6.2 percent in 2015, further more East African stock markets has same and unique characteristics of BOD.

In EAC context, the BSC challenges has been addressed by privatization policy and capital market authorities, However, in the worldwide context the BSC challenges has been addressed by different organizations including the Organization for Economic and Cooperation Development (OECD) and Commonwealth Association for Corporate Governance (CACG) which have led to the development of effective corporate governance principles. According to World Bank (2000) report, governance crises caused by factors including the weak legal and regulatory systems, inconsistent accounting and auditing standards, poor banking practices, thin and poorly regulated capital markets, ineffective oversight of the BOD and little regards for the rights of minority shareholders. In recent years, many researchers have been investigating the impact of BSC on capital structure of a firm. The increase of these studies relating to BSC and firm decisions is not surprising as the days going on and these is due to the following facts; the firms are increases in size (become multinational firms); growing business complexities, bankruptcy and collapse of firms; financial crises (like Asian economic crisis etc.) and frauds and earning management

However, despite the substantial prior empirical evidences on the relationship between BSC and CSD but still it's a researchable and puzzling issue in corporate finance literature and this is due to the following facts. First, No study on the effects of BSC on CSD has focused on EAC context, despite this regional bloc is now become the fastest growing region in Sub Saharan African for the past 10 years (effective from 2005) with an average GDP growth of 6.2 percent on 2015, simply put EAC context interesting and very important. Therefore, leaving significant doubt about the applicability of previous empirical evidences in East African region business environment. Second, majority of prior empirical studies were considering the developed economies with very few studies which focused on developing economies, despite those prior studies still there is shortcomings due to the followings facts (i) Developed economies and developing economies differs as business environment is concern so we cannot rely from the developed economies findings and conclusions to conclude 
about the firm behavior in EAC context, Hove (1986 \& 1990) asserted the important role played by political, economic and social systems in corporate decision. (ii) Many studies from other developing economies were utilized small samples (one stock market or industry), few variables on measuring the BSC and the CSD of a firm and considered a very short period of time (less than 10 years). Third, Inconclusive (mixed) empirical evidence, however; still the results from prior studies cannot be generalized as the effect of BSC on CSD is concerned due to mixed results. Other empirical studies found a positive effects of BSC on CSD but other studies found a negative effects and others found no effect at all of BSC on CSD.

In this research, the main objective was to examine the impact of board structure characteristics on capital structure decisions of listed firms in East African stock markets context. Our results from this study have important implications for managers of listed firms in East African regional bloc, investors (both private individuals investors and institutional investors), regulatory authorities in the East African regional bloc (Including CMA in Kenya, CMSA in Tanzania, CMA in Uganda, CMA in Rwanda and EASRA), board of directors (BOD) of listed firms in the East African region and debt holders (like Commercial bank.

The rest of this paper is organized as follows: Section 2 presents relevant literatures review, theoretical foundation and research hypotheses, Section 3 is about research methodology applied in this study, Section 4 presents study results and discussion of findings and lastly Section 5 concludes the paper and give out recommendations.

\section{Literature Review}

\subsection{Prior Empirical Studies}

It is widely accepted that the board of directors (BOD) is a key and most effective corporate governance practice (CGP), with an effective function in reducing different types of agency problems and making sure the firm operate in a very competitive style and efficient manner (Jensen and Meckling, 1976; Jensen, 1993).In generally view, the BOD is the firm highest organ for decision making and responsible for directing managers with strategies and guidelines relating to capital structure decisions (Sheikh and Wang,2012; Hussainey and Aljifri, 2007).

Prior empirical studies investigated the effects of the BOD on CSD due to its importance on firm survival, and the results relating to these variables are still contradictory. Theoretically, firms with effective BOD can enjoy than firms with ineffective BOD due to more diversity in terms of experience and skills, which in turn allow them to mitigate agency problems in effective manner (Pfeffer, 1972; Jensen and Meckling, 1976; Klein, 2002).According to Jensen (1993) ineffective BOD are likely to be dominated by firm managers, whereby firm managers will put pressure on BOD, this idea suggesting that firm with ineffective BOD may need to adopt a higher level of debt in order to reduce such pressure from managers and align managers interest with those of owners interest.

In a line with positive expectation of the theoretical literature, a number of prior studies 
offered a positive effect of board structure characteristics on capital structure decisions. e.g.: Wen et al., (2002) reported a positive effect of BSC (board size) on CSD on his study using Chinese listed firms. Furthermore, Ranti (2013), found a significant positive effect of BSC (CEO duality) on CSD for Nigeria stock exchange listed firms from 2006-2011, Sheikh and Wang (2012) using 155 Pakistan listed firms from 2004 to 2008 documented a statistically significant and positive effect of BSC on CSD (both on total debt and long term debt), and both Wang et al., (2012), using 145 selected SMEs in Taiwan and Yaseen and Amarneh (2013), using selected firms in Jordanian stock exchange from 2005 to 2011, documented a significant positive effects of BSC (directors' ownership) on CSD.

In contrast, other prior studies documented a negative effects of BSC on CSD like Akbari and Rahmani (2013), using Iran firms listed in Tehran stock exchange they documented a significant negative effects of BSC (both non-executive directors and CEO duality) on CSD, Ngan (2013), documented a significant negative effect of BSC (both board size and board composition) on CSD using listed firms in Hochiminh city stock exchange in Vietnam from 2010 to 2011, Babalalo and Yinusa (2012), using listed firms in Nigeria stock exchange documented a negative effect of BSC (biography/board skill and CEO duality) on CSD, Al-Najjar and Hussainey (2011), using 379 listed firms in United Kingdom from 1991 to 2002, Masnoon and Rauf (2014), using 30 Pakistan firms listed in Karachi stock exchange they documented a statistically significant and negative effects of BSC (both non-executive directors and CEO duality) on CSD from 2009-2011 and both Mehran (1992) and Berger et al.,(1997) reported the negative effect of firm BSC (board size) on CSD on their studies.

Moreover, other researcher like Hussainey and Aljifri (2007), using listed firms in United Arabs of Emirates (UAE) did not find significant impact of BSC (board size) on CSD, Rehman et al., (2010), using 19 selected firms in Pakistan did not find significant impact of BSC (board independence) on CSD. Furthermore, Kajananthan (2012), using 28 selected manufacturing listed firms in Sri Lanka did not find any significant effect of BSC (board meeting) on CSD, Priya and Nimalathasan (2013), using 15 selected hotels and restaurant in Sri Lanka they documented insignificant effects of BSC (board of directors meeting, CEO duality, board composition and board size) on CSD from 2008-2012, Brenni (2014), using 26 UK listed real estate firms listed in London stock exchange documented insignificant effects of BSC (non-executive directors and CEO duality) on CSD from 2000-2009 and Chitiavi et al., (2013), using Kenyans firms listed at Nairobi securities exchange they documented insignificant effects of BSC (both board size and board independence) on CSD from 2007-2011.

\subsection{Theoretical Foundation and Hypotheses}

Resource dependence theory (RDT) context relates to the idea that competitive advantage arises from organization heterogeneity which brings about the potential function of corporate governance as a firm resource generator and not a firm distributor or protector as considered in AT. RDT concentrate on the function played by board of directors (BOD) in providing access to all required resources needed by the firm. Furthermore, this theory link on how external resources of the firm affect its behaviors. According to Barney (1991) if a firm 
possess both tangible and intangible resources which are very unique and rarely available to other firms then this firm have a competitive advantages over other firms. Firms are operating in a very competitive business environment for this case a firm is supposed to recognize on how to sustain competitive advantage. According to Pfeffer and Salancik (1978) that RDT has developed the concept of optimal structure of BOD, strategies on production but also external relationships as well as other aspects of firm strategy, moreover, firm's BOD size and its composition are the rational reaction to the conditions of external environment. The firm BOD viewed as a linking network that connects the firms with its external environment (Hillman et al., 2009). The RDT proposed the link between BOD and acquiring of firm resources such as capital etc. for its success, but also RDT suggested that most of the firm decisions be made by management team with some approval of the BOD. In general speaking, RDT context is all about how BOD direct involved in firm decision making process

RDT suggested the intervention of the BOD while advocating for strong financial, human and intangible supports to management team. According to Johnson (1999), RDT emphasis on the appointment of representative's independent organizations as a way forward for to firms getting access of resources for their success. For instance, appointing outside directors who are financial analyst (partners) to a financial consultant firm, this will help an organization because these outside directors will also give financial advice (e.g. financing decision like CSD) to the organization, either during board meetings or through private meetings (communications) with the organization management team that may otherwise be very expensive for the organization to secure. The general idea behind RTD is on how BOD who are professionals (e.g. Certified Financial Analyst (CFAs), Certified Professional Accountants (CPAs), and Certified Professional Bankers (CPBs), Lawyers/Advocates) may use their area of expertise to train and mentor the management team in a good way that will help firm success. Moreover, the BOD can trap into their networks of support to attract firm needed resources.

Daily et al., (2003) argued the role of resource provision to enhance firm functioning, performance and survival. According to Hillman et al., (2009) that BOD provide resources to the organization such as skills, information, access to key constituents like customers, suppliers, public policy makers, social groups and legitimacy. Furthermore, BOD can be classified into four (4) categories such as; (I) Insiders (such as current and former management team of the organization), these group of directors will help to provide expertise in specific areas like finance and law but also the general firm strategy and firm direction, (II) Business experts (such as current, former senior management team and directors of large for profit making firms), these group of directors will help on issues like business strategy, firm decision making and also problem solving, (III) Support specialist (such as bankers, lawyers/advocates, insurance company representatives also public relation expertise), these group of directors will support the firm in their individual specialized area and last category (IV) Community influential (such as political leaders, university staffs and also leaders of social or community organizations), these group of directors will help the firm to advocate the good reputation (image) of the firm to the general public at large.

According to Dalton et al., (2003) argued that RDT link the expected firm benefits arising 
from different types of ownership structure such as large institutions, foreign, government etc. It should be noted that different groups of shareholders have different capabilities of providing unique and rare resources to the firm so as to create a competitive advantage. For instance, Douma et al., (2006) argued that foreign investors who, as opposed to domestic investors, are associated with a very good monitoring capabilities and by using their stakes they secure new markets for the firm's services or goods but also secure access to location-specific resources and low cost production facilities.

In our current study, we are expecting that firm with effective board structure characteristics (BSC) will attract debt capital easily due to their expertise, skills and prestige; hence the BSC had a positive effect on CSD.

Hla: There is a statistically significant positive relationship between board structure characteristics and short term debt.

H1b: There is a statistically significant positive relationship between board structure characteristics and long term debt.

H1c: There is a statistically significant positive relationship between board structure characteristics and total debt.

\section{Research Methodology}

\subsection{Scope, Population and Sample Size}

Our research use all publicly listed firms on East African stock markets during the period of 2006-2015. East African region bloc currently comprises of six (6) Partner States such as Kenya, Tanzania, Uganda, Rwanda, Burundi and South Sudan. In selecting listed firms, the current research has set specific criteria in order for a particular listed firm to be included in our final sample. First, a listed firm must have the required financial data and board structure characteristics data for a period of ten (10) years (i.e. 2006-2015).This criterion was applied for the following reasons; (I) The financial year 2006 is the first year after the implementation of the first EAC objective (i.e. Customs Union ) (II) The financial year 2015 is the last year for our research data because it is the most recent year for which financial data and board structure characteristics data was available at data collection period (III) using a ten (10) years dataset distinguishes our current research from prior empirical studies that employ dataset for less number of years (short period of time),finally this long period of time may help our current research in ascertaining whether BSC - CSD link holds over time. Second, all cross listed firms within East African stock market were excluded in order to eliminate duplication of data. Third, all financial listed firms, including all financial institutions, banks and insurance companies listed in East African stock markets were excluded from our current research. This criterion was applied for the following reasons; (I) the capital structure of these financial firms is highly regulated, for instance banks are regulated by central banks and insurance companies are regulated by respective insurance regulatory authorities. (II) Cash is trading assets of bank, therefore, banks cash holding levels are expected to be significant higher compared to other listed firms in other sectors (Mwangi et al., 2014).Fourth, a mining 
listed firm was also excluded from the research due to its big different in capital structure and nature of operations as compared to other listed firms in East African stock market (Mwambuli, 2016b).Fifth, all newly listed firms and delisted firms during the research period were also excluded in order to remove any anomalies (Mwambuli, 2016a). Sixth, the research eliminated some listed firms due to unavailability or insufficient of both or either financial data or board structure characteristics data for the period of study. Seventh, Unlike many prior studies that includes only large listed firms in their study samples, our research includes all listed non-financial listed firms for which is not cross listed with East African stock market and there is availability of data in order to enhance the generalization of our results in this current research. Finally, the sampled listed firms in this current research comprises of 32 out of 38 non-financial firms listed on East African stock market, which represents $84 \%$ of total population in East African region bloc and this is consistent with what has been suggested by Krejcie and Morgan (1970) that appropriate sample size is 5\% of total population. However, we made a lot of efforts to obtain missing financial and board structure characteristics data from respective firms; we contracted them physically, by email and phone during the data collection period. They did not respond, leaving our current research with a sample size of 32 firms. In addition, our final sample includes firms from all six (6) industries (Note 3) (sectors) in the East African stock markets including manufacturing and allied, construction and allied, commercial and services, agricultural, energy and petroleum and automobile and accessories.

\subsection{Data Sources}

Our research used two (2) types of data: financial data and board structure characteristics data. Using a content analysis approach, our current research manually extracted both financial and board structure characteristics data from listed firm's annual reports. The listed firms annual reports were collected from various sources: the main source was OSIRIS database and supplemented with East African stock market's websites and firm's websites. Furthermore, the IMF and World Bank websites were also used to collect macroeconomic data for the EAC. Finally; in our current research we made a critical review of academic literature from financial journals, books and articles to form a foundation of the research.

\subsection{Board Structure Characteristics and Capital Structure Decisions Variables Measurements and References}

Our research used capital structure decisions (CSD) as dependent variable and the board structure characteristics index (BSCI) as independent variable while firm size, level of economic development and industry dummies were also considered as control variables on analyzing the effects of board structure characteristics on capital structure decision in East African stock market context. This Subsection discusses variables measurements (proxies) with their respective references. 
Table 1. Summary of Dependent Variables

\begin{tabular}{|c|c|c|c|}
\hline Variable & Indicators & Measurement & Reference \\
\hline \multirow{6}{*}{$\begin{array}{l}\text { Capital Structure } \\
\text { Decision }\end{array}$} & \multirow{2}{*}{ Short Term Debt Ratio } & Current Liabilities & (e.g. Mwambuli, 2016a; \\
\hline & & Total Assets & $\begin{array}{l}\text { and Danbolt, 2002) } \\
\text { and Dinam, }\end{array}$ \\
\hline & \multirow{2}{*}{ Long Term Debt Ratio } & Non Current Liabilities & (e.g. Mwambuli, 2016a; \\
\hline & & Total Assets & $\begin{array}{l}\text { linasithamy, 2014; } \\
\text { and Danbolt, 2002) }\end{array}$ \\
\hline & \multirow{2}{*}{ Total Debt Ratio } & Total Liabilities & (e.g. Mwambuli, 2016a; \\
\hline & & Total Assets & and Danbolt, 2002) \\
\hline
\end{tabular}

Source: Researcher (2017)

The current research constructs the board structure characteristics index (BSCI) in order to perform its empirical part in the next Section. The BSCI consists of 10 board structure characteristics practices that were adopted from the prior study of Black et al., (2006) but with major modifications in a line with the East African code of good corporate governance practices. Thus, we choose only 10 provisions because those provisions are highly correlated with capital structure decisions. According to Monda and Giorgino (2013) it's not suggested to choose complex indices with provisions which are not highly correlated with study matter, because it will lead to wrong measures of the quality of firm corporate governance and also while using them will attract firms to adopt a counter-productive corporate governance practices.

Table 2. Board Structure Characteristics Index (BSCI) Provisions Applied to East African Stock Market Listed Firms

\section{Board Structure Characteristics}

1. Is the board size between 6 and 9 members?

2. Is the role and functions of the board stated?

3. Are the Chairman of the board and the CEO not the same person?

4. Is there information about independent directors?

5. Is there board meeting attendance?

6. Is outside directors' attendance in meetings?

7. Is there existence of the position of CFO?

8. Do directors representing minority shareholders?

9. Is there biography of the board members?

10. Is a change in the board structure indicated?

Source: Researcher (2017)

In line with prior capital structure studies, which found that capital structure decisions is influenced with some firm characteristics and external factors (e.g. macroeconomic indicators), the current research includes a number of control variables. This is expected to mitigate potential statistical problems related to omitted variables, such as endogeneity problems. These control variables include firm size, level of economic development and industry dummy (See Table 3.3-Summary of Control Variables). 
Table 3. Summary of Control Variables

\begin{tabular}{|c|c|c|c|}
\hline Variable & Indicators & Measurement & Reference \\
\hline \multirow[t]{7}{*}{ Control } & Firm size & Natural logarithm of total assets & $\begin{array}{l}\text { Mwambuli (2016b), Smith et al., } \\
\text { (2012), Dewalheyns and Van } \\
\text { Hule (2012) and Ebaid (2009)) }\end{array}$ \\
\hline & $\begin{array}{ll}\text { Level of } \\
\text { economic }\end{array}$ & Annual real GDP growth & Srairi (2015) \\
\hline & $\begin{array}{l}\text { Industry } \\
\text { dummies(Note } 4)\end{array}$ & $\begin{array}{l}\text { DI = "1", If the observation belongs to } \\
\text { manufacturing and allied industry and } \\
\text { "O" otherwise. }\end{array}$ & Mwambuli (2017a) \\
\hline & & $\begin{array}{l}\text { D2 = "1", If the observation belongs } \\
\text { construction and allied industry and "O" } \\
\text { otherwise. }\end{array}$ & \\
\hline & & $\begin{array}{l}\text { D3 = "1", If the observation belongs to } \\
\text { commercial and services industry and "O" } \\
\text { otherwise. }\end{array}$ & \\
\hline & & $\begin{array}{l}\text { D4 = "1", If the observation belongs to } \\
\text { agricultural industry and "O" otherwise. }\end{array}$ & \\
\hline & & $\begin{array}{l}\text { D5 = " } 1 " \text {, If the observation belongs to } \\
\text { energy and petroleum industry and "O" } \\
\text { otherwise. }\end{array}$ & \\
\hline
\end{tabular}

Source: Researcher (2017)

\subsection{Data Analysis and Model Specifications}

The financial data and board structure characteristics data obtained for listed firm on East African stock was analyzed using descriptive and inferential statistics. Descriptive statistics of variables were calculated for the whole period of study (2006-2015), then correlation analysis was employed to measure the extent of relationship among variables used in this study and panel multiple regression models to identify the most significant and influential independent variables on dependent variable. The panel methodology was done by using E-VIEWS 8 and STATA 10 statistical packages and our panel dataset comprises of 320 observations.

Our research employs multiple linear regression analysis and uses Ordinary Least Square (OLS) as an estimation method. In line with prior studies and assuming that all predicted relations are linear. The following regression models Model 1 ( $a, b$ and $c$ ) were applied in our current research;

Model 1 - (Board Structure Characteristics and Capital Structure Decisions)

STDR $_{\text {it }}=\beta_{0}+\beta_{1}$ BSCI $+\sum_{i=1}^{n}\left(\beta_{i}\right.$ CONTROLS $)+\varepsilon_{\mathrm{it}}$ 
$\operatorname{LTDR}_{\mathrm{it}}=\beta_{0}+\beta_{1} \mathrm{BSCI}+\sum_{i=1}^{n}\left(\beta_{i}\right.$ CONTROLS $)+\varepsilon_{\mathrm{it}}$

$\mathrm{TDR}_{\mathrm{it}}=\beta_{0}+\beta_{1} \mathrm{BSCI}+\sum_{i=1}^{n}\left(\beta_{i}\right.$ CONTROLS $)+\varepsilon_{\mathrm{it}}$

Where

STDR $_{\text {it }}$

LTDR $_{\text {it }}$

$\mathrm{TDR}_{\text {it }}$

$\beta_{0}$

$\beta_{1}$

BSCI

$\beta_{i}$

CONTROLS

dummies.
Short term debt ratio of firm $i$ at time $t$

Long term debt ratio of firm $i$ at time $t$

Total debt ratio of firm $i$ at time $t$

Intercept coefficient

Coefficient of the concerned independent variable.

Board Structure Characteristics Index

Coefficient of the control variable.

Control variables for firm size, level of economic development and industry

$\varepsilon_{\text {it }}$

Error term of firm i at time $\mathrm{t}$

\subsection{Tests of Statistical Assumptions}

A number of statistical tests were conducted to check the regression model assumption validity. The statistical test results are reported on sub-section below.

\subsubsection{Linearity Test}

Our research run linearity test using ANOVA test. This test has a power to compute the linear components and nonlinear components of a pair of variables. The linearity indicating the linear relationships (constant slope) between the independent variables and dependent variable. The following hypothesis was considered for the linearity test.

Null hypothesis (Ho): Panel data is linearly distributed.

Alternative hypothesis (H1): Panel data is not linearly distributed.

Table 4 presents the ANOVA test results. The ANOVA test results suggest that all variables in our research are linearly distributed at 5\% significance level, therefore our research accepted our null hypothesis that our strongly panel dataset is linearly distributed. 
Table 4. Linearity Test (ANOVA test)

\begin{tabular}{cccc}
\hline & & $\begin{array}{c}\text { Number of } \\
\text { observations }\end{array}$ & p-value \\
\hline $\begin{array}{c}\text { Threshold: Assumption is met } \\
\text { if }\end{array}$ & & & $\mathrm{p}>0.050$ \\
\hline & TDR & 320 & 0.314 \\
Panel A-Dependent Variables & LTDR & 320 & 0.126 \\
& STDR & 320 & 0.381 \\
Panel B-Independent Variables & BSCI & 320 & 0.592 \\
Panel C-Control Variable & SIZ & 320 & 0.252 \\
& GDP & 320 & 0.448 \\
\hline
\end{tabular}

Source: STATA 10 Analysis of Data

\subsubsection{Normality Test}

Our research run normality test using Shapiro-Wilk test. This test has a power to be detect departure from normality that resulted from either or both skewness and kurtosis. The Shapiro-Wilk test is appropriate for a sample size between 7 and 2000 (Shapiro and Wilk, 1965). The normality indicating that the sampling distribution of the mean is normal. The following hypothesis was considered for the normality test.

Null hypothesis (Ho): Panel data is normally distributed.

Alternative hypothesis (H1): Panel data is not normally distributed.

Table 5 presents the Shapiro-Wilk test results. The Shapiro-Wilk test results suggest that all variables in our research are normally distributed at 5\% significance level, therefore our research accepted our null hypothesis that our strongly panel dataset is normally distributed.

Table 5. Normality Test

\begin{tabular}{cccc}
\hline & & Number of observations & p-value \\
\hline Threshold: Assumption is met if & & & $\mathrm{P}>0.050$ \\
\hline \multirow{3}{*}{ Panel A-Dependent Variables } & TDR & 320 & 0.107 \\
& LTDR & 320 & 0.263 \\
& STDR & 320 & 0.190 \\
Panel B-Independent Variables & BSCI & 320 & 0.449 \\
& SIZ & 320 & 0.185 \\
Panel C-Control Variable & GDP & 320 & 0.359 \\
\hline
\end{tabular}

Analysis of Data Source: STATA 10 


\subsubsection{Multicollinearity Test}

\subsubsection{Unit Root Test (Stationarity Test)}

The econometric regression model will produce spurious or non-sensible regression results relating to the relationship between dependent and independent variables when non-stationary data were employed in analysis. Non-stationary data this is when a data series does not have a constant mean variance and auto-covariance at various lags over time (Gujarati, 2007, Hossain. I and Hossain. A, 2015, Mwambuli, 2015, Mwambuli, 2016b).

Our research run unit root test as proposed by Levin-Lin- Chu (LLC). We used LLC test in our research because we employed a strongly balanced panel dataset. The following hypothesis was considered for the unit root test.

Null hypothesis (Ho): Panel data contains unit root [non-stationary].

Alternative hypothesis (H1): Panel data is stationary.

Table 7 presents the LLC test results. The LLC results suggest that all variables in our research are stationary at both individual intercept and individual intercept and trend, except BSCI is non-stationary at individual intercept but is stationary at individual intercept with trend. However, the assumption with individual intercept and trend is a better estimator of unit root as compared to individual intercept only; therefore BSCI has been treated as stationary data series. Our research run this unit root test considering p-value is significant at 5\% significance level, therefore our research rejected our null hypothesis and we accepted our alternative hypothesis that our strongly panel dataset are stationary.

Table 7. Unit Root Test Results-Levin, Lin and Chu (LLC) test

\begin{tabular}{|c|c|c|c|c|c|c|}
\hline \multicolumn{7}{|c|}{ Null: Unit root (assumes common unit root process) } \\
\hline & \multicolumn{3}{|c|}{ With individual intercept } & \multicolumn{3}{|c|}{ With individual intercept and trend } \\
\hline Variable & t-statistic & Probability & Process & t-statistics & Probability & Process \\
\hline TDR & -10.218 & 0.000 & Stationary & -25.953 & 0.000 & $\overline{\text { Stationary }}$ \\
\hline LTDR & -20.258 & 0.000 & Stationary & -15.653 & 0.000 & Stationary \\
\hline STDR & -8.140 & 0.000 & Stationary & -10.547 & 0.000 & Stationary \\
\hline BSCI & -1.152 & 0.125 & Non-Stationary & -7.113 & 0.000 & Stationary \\
\hline SIZ & -15.176 & 0.000 & Stationary & -10.940 & 0.000 & Stationary \\
\hline GDP & -16.541 & 0.000 & Stationary & -94.012 & 0.000 & Stationary \\
\hline
\end{tabular}

Source: E-VIEWS 8 Analysis of Data

\subsubsection{Heteroscedasticity Test}

Our research use White test to check for the presence of heteroskedasticity in our econometric regression models. This test is very appropriate because the presence of heteroskedasticity in our dataset will lead to inaccurate values of t-test and F-test, therefore our results will be misleading. Heteroskedasticity arise when errors do not have constant 
variance, Gujarati (2007). The following hypothesis will be applied for our econometric regression models.

Null hypothesis (Ho): Absence of heteroskedasticity

Alternative hypothesis (H1): Presence of heteroskedasticity

Table 8 presents heteroskedasticity test results for model 1 (BSCI and CSD). The White test statistics presents the following $\mathrm{p}$ values; $0.000,0.000$ and 0.000 for model $1 \mathrm{a}-\mathrm{STDR}$, model 1b-LTDR and model 1c-TDR respectively. The White test results presents significant $\mathrm{p}$ values for model 1a-STDR, model $1 \mathrm{~b}$-LTDR and model 1c-TDR at 5\% significance level and this suggesting that the model 1a-STDR, model $1 \mathrm{~b}-\mathrm{LTDR}$ and model $1 \mathrm{c}-\mathrm{TDR}$ are facing heteroskedasticity problem (presence of heteroskedasticity).

Table 8. Heteroskedasticity Test Results-Model 1 (BSCI and CSD)

\begin{tabular}{llll}
\hline Heteroskedasticity Test: White & & \\
\hline & Model 1a-STDR & Model 1b-LTDR & Model 1c-TDR \\
\hline F-statistic & 2.945 & 3.648 & 3.704 \\
Prob. F(26,293) & 0.000 & 0.000 & 0.000 \\
Obs*R-squared & 66.292 & 78.262 & 79.167 \\
Prob.Chi-Square (26) & 0.000 & 0.000 & 0.000 \\
Scaled explained SS & 131.603 & 167.545 & 313.971 \\
Prob.Chi-Square (26) & 0.000 & 0.000 & 0.000 \\
\hline
\end{tabular}

Source: E-VIEWS 8 Analysis of Data

\subsubsection{Autocorrelations Test}

Our research used Breusch-Godfrey Serial correlation LM test to check for autocorrelation in the econometric regression models. We run this test because we employed strongly balanced panel dataset therefore the possibility of having autocorrelation cannot be ignored. Autocorrelation arises when errors associated to a given time period carry over into future time periods. The presence of autocorrelation in dataset will lead to misleading results in our econometric regression models. The following hypothesis will be used for our econometric regression models.

Null hypothesis (Ho): Absence of autocorrelation

Alternative hypothesis (H1): Presence of autocorrelation

Table 9 presents autocorrelation test results for model 1 (BSCI and CSD). The Breusch-Godfrey Serial Correlation test statistics presents the following $\mathrm{p}$ values; 0.000, 
0.000 and 0.000 for model 1a-STDR, model $1 \mathrm{~b}-\mathrm{LTDR}$ and model 1c-TDR respectively. The Breusch-Godfrey Serial Correlation test results presents significant $p$ values for model 1a-STDR, model 1b-LTDR and model 1c-TDR at 5\% significance level and this suggesting that the model 1a-STDR, model 1b-LTDR and model 1c-TDR are facing autocorrelation problem (presence of autocorrelation).

Table 9. Autocorrelation Test Results-Model 1 (BSCI and CSD)

\begin{tabular}{llll}
\hline \multicolumn{3}{l}{ Breusch-Godfrey Serial Correlation LM Test: } & \\
\hline & Model 1a-STDR & Model 1b-LTDR & Model 1c-TDR \\
\hline F-statistic & 335.521 & 260.219 & 356.646 \\
Prob. F(2,310) & 0.000 & 0.000 & 0.000 \\
Obs*R-squared & 218.854 & 200.545 & 223.050 \\
Prob.Chi-Square (2) & 0.000 & 0.000 & 0.000 \\
\hline
\end{tabular}

Source: E-VIEWS 8 Analysis of Data

\subsubsection{Panels Corrected Standard Errors (PCSEs) Regression Model}

We employ Panel Corrected Standard Errors (PCSEs) regression model because our model are facing heteroscedasticity and autocorrelation problems. The PCSEs model will correct the problems automatically and models will present reliable best estimates for our variables. Kmeta (1997) argued that PCSEs as an alternative to the Feasible Generalized Least Square (FGLS) for fitting the panel data models when the errors are not independent and identically distributed; rather the errors are either heteroskedastic across panels or heteroskedastic and contemporaneously correlated across panels, with or without autocorrelation (Hossain. I and Hossain. A, 2015, Mwambuli, 2016a).

\section{Results and Discussion of Findings}

\subsection{Descriptive Analysis}

Table 4.1 presents the descriptive statistics for the dependent variables, independent variable and control variable. It shows that the total debt ratio (TDR) for East African listed firm's ranges from a minimum of $12.2 \%$ to a maximum of $205.2 \%$, with an average total debt ratio of $54.2 \%$ for the period 2006 to 2015.This indicates that East African listed firms are highly leverage, which is in line with the same results reported by Mwambuli (2016a). The higher average value of the total debt suggests that East African firms depend much on debt financing than equity financing. Furthermore, the long term debt ratio (LTDR) for East African listed firm's ranges from a minimum of $0 \%$ to a maximum of $102.6 \%$, with an average long term debt ratio of $23.3 \%$ for the period 2006 to 2015 while the short term debt ratio (STDR) ranges from a minimum of $4.0 \%$ to a maximum of $102.6 \%$, with an average short term debt ratio of $30.9 \%$ for the period of 2006 to 2015. This indicates that, the corporate debt structure for East African regional bloc listed firms is highly depending on 
short term financing (like Bank borrowings) than long term financing. Such managerial preference for East African listed firms to depending much on debt financing and especially short term sources of finances might be contributed by several reasons ; (I) Less developed capital markets in the East African region bloc that make firms to depend much from banks and financial institutions rather than capital markets; (II) East African listed firms with large block holders in their ownership structure, might tend to use debt financing as a corporate governance practice in order to discipline firm managers. However, the standard deviation for total debt ratio, long term debt ratio and short term debt ratio are $31.1 \%, 19.5 \%$ and $18.8 \%$ respectively, indicating that there is a small variation in the total debt ratio, long term debt ratio and short term debt ratio among the East African regional bloc listed firms.

Table 10. Descriptive Statistics (Overall)

\begin{tabular}{|c|c|c|c|c|c|c|c|}
\hline & & Mean & Median & Maximum & Minimum & $\begin{array}{l}\text { Standard } \\
\text { Deviation }\end{array}$ & $\begin{array}{l}\text { Number of } \\
\text { Observation }\end{array}$ \\
\hline \multirow{3}{*}{$\begin{array}{l}\text { Panel A-Dependent } \\
\text { Variables }\end{array}$} & TDR & 0.542 & 0.509 & 2.0516 & 0.122 & 0.311 & 320 \\
\hline & LTDR & 0.233 & 0.181 & 1.026 & 0.000 & 0.195 & 320 \\
\hline & STDR & 0.309 & 0.272 & 1.025 & 0.040 & 0.188 & 320 \\
\hline $\begin{array}{l}\text { Panel B-Independent } \\
\text { Variable }\end{array}$ & BSCI & 6.444 & 6.000 & 10.000 & 1.000 & 1.952 & 320 \\
\hline $\begin{array}{l}\text { Panel C -Control } \\
\text { Variable }\end{array}$ & SIZ & 22.536 & 22.556 & 25.939 & 15.431 & 1.423 & 320 \\
\hline
\end{tabular}

Source: E-Views 8 Analysis of Data

In addition, Table 10 show the board structure characteristics index (BSCI) ranges from a minimum score of 1 governance practice to a maximum of 10 governance practices, with an average score of 6 governance practices for the period of 2006 to 2015.This indicates that listed firms in East African stock markets have complied with 6 of board structure provisions out of 10 suggested board structure provisions and this suggests a medium level of compliance for board structure governance provisions to East African listed firms. Finally, the firm size (SIZ) measured as natural logarithm of total assets is 23; this indicates that East African listed firms are large firms in average as measured in terms of total assets.

\subsection{Regression Analysis}

Table 11 presents the regression results from the Panel Corrected Standard Errors (PCSEs) for Model 1a-STDR.The results indicates that board structure characteristics index (BSCI) has a statistically insignificant effect on capital structure decision of East African listed firms as measured by short term debt ratio (STDR) at 5\% significance level. The coefficient and $p$ value of the BSCI are -0.009 and 0.125 respectively. This results suggesting that the BSC is negatively related to CSD (short term debt) for East African region bloc listed firms but the results are not statistically significant. Our results are consistency with prior empirical results reported by Rehman et al (2010). Moreover, this results is inconsistency with the research dependence theory (RDT) which suggested that the BOD are key person to bring required 
resources (e.g. finance etc.) for firm success. Furthermore, our empirical results indicate a statistically significant effects of firm size (SIZ) and annual real gross domestic product (GDP) growth (i.e. control variables) on CSD (short term debt) at 5\% significance level. The coefficients of SIZ and GDP are -0.023 and -1.082 respectively and their p-values are 0.002 and 0.028 for SIZ and GDP respectively. This results suggesting that larger firms in East African regional bloc adopt a low level of short term debt in their capital structure and the reason behind this situation might be due to several reason and one of the key reason is the fact that larger firms may easily obtained long term funds from lenders or issuing equity at a lowest cost due to their good credit ratings, and the annual real GDP growth has a negative and statistically significant effects on CSD (short term debt) and this might be due to fact that when a country experience a positive growth in economy, then firms operating in that country will get profits from their operations and their retained earnings will also increases as results they will decide to use internal sources (retained earnings) before they opt for external sources (short term debt) as suggested by the pecking order theory (POT), thus firms operating in the East African country with higher GDP will tend to employ low level of short term debt in their capital structure. Table 11 also indicates the firm's industrial effect on CSD (short term debt) is statistically significant but the coefficients of industry variable are not reported. Finally, table 11 reported the prob $>$ chi2 of 0.000 at $5 \%$ significance level, suggesting that our model 1a-STDR is statistically significant. Our empirical results are consistent with prior empirical study reported by Rehman et al (2010), therefore, we rejected the hypothesis H1a.

Table 11. Panel Corrected Standard Errors (PCSEs) Model Results-Model 1a

\begin{tabular}{lllll}
\hline \multicolumn{5}{c}{ Model 1a: STDR } \\
\hline Variable & Coefficient & Std. Error & t-statistics & Probability \\
\hline Intercept & 1.004 & 0.168 & 5.99 & 0.000 \\
BSCI & -0.009 & 0.006 & -1.54 & 0.125 \\
SIZE & -0.023 & 0.007 & -3.08 & 0.002 \\
GDP & -1.082 & 0.492 & -2.20 & 0.028 \\
Industry Fixed Effects & Yes & & & \\
Number of Observations & 320 & 0.272 & & \\
R-squared & 819.460 & & & \\
F-statistics & 0.000 & & & \\
Probability (F-statistics) & & &
\end{tabular}

Table 12 presents the regression results from the Panel Corrected Standard Errors (PCSEs) for Model 1b-LTDR. The results indicates that board structure characteristics index (BSCI) has a statistically significant effect on capital structure decision of East African listed firms as measured by long term debt ratio (LTDR) at 5\% significance level. The coefficient and $\mathrm{p}$ value of the BSCI are -0.015 and 0.024 respectively. This results suggesting that the BSC is negatively related to CSD (long term debt) for East African region bloc listed firms and the results are statistically significant. The East African listed firms with better BSCI tends to 
employ a low level of long term debt on their capital structure. Our results are consistency with prior empirical results reported by Abor and Biekpe (2007). Moreover, this result is inconsistency with the research dependence theory (RDT) which suggested that the BOD are key person to bring required resources (e.g. finance etc.). Furthermore, our empirical results indicate a statistically insignificant effects of both firm size (SIZ) and annual real gross domestic product (GDP) growth (i.e. control variables) on CSD (long term debt) at 5\% significance level. The coefficients of SIZ and GDP are +0.012 and -0.508 respectively and their p-values are 0.195 and 0.244 for SIZ and GDP respectively. This results suggesting that size of firms in East African regional bloc is positively related to CSD (long term debt) although its effects is statistically insignificant and the country annual real GDP growth is negatively related with CSD (long term debt) but its effects is also statistically insignificant. Table 12 also indicates the firm's industrial effect on CSD (long term debt) is statistically significant but the coefficients of industry variable are not reported. Finally, table 12 reported the prob>chi2 of 0.000 at $5 \%$ significance level, suggesting that our model $1 b$-LTDR is statistically significant. Our empirical results are consistent with prior empirical study reported by Abor and Biekpe (2007), therefore, we rejected the hypothesis H1b.

Table 12. Panel Corrected Standard Errors (PCSEs) Model Results-Model 1b

\begin{tabular}{lllll}
\hline \multicolumn{3}{c}{ Model 1b: LTDR } \\
\hline Variable & Coefficient & Std. Error & t-statistics & Probability \\
\hline Intercept & -0.079 & 0.198 & -0.40 & 0.689 \\
BSCI & -0.015 & 0.007 & -2.26 & 0.024 \\
SIZE & 0.012 & 0.009 & 1.30 & 0.195 \\
GDP & -0.508 & 0.436 & -1.16 & 0.244 \\
Industry Fixed Effects & Yes & & & \\
Number of Observations & 320 & & & \\
R-squared & 0.100 & & & \\
F-statistics & 888.780 & & & \\
Probability (F-statistics) & 0.000 & & & \\
Source: STATA 10 Analysis of Data & & &
\end{tabular}

Table 13 presents the regression results from the Panel Corrected Standard Errors (PCSEs) for Model 1c-TDR.The results indicates that board structure characteristics index (BSCI) has a statistically significant effect on capital structure decision of East African listed firms as measured by total debt ratio (TDR) at 5\% significance level. The coefficient and $p$ value of the BSCI are -0.024 and 0.031 respectively. This result suggests that the $\mathrm{BSC}$ is negatively related to CSD (total debt) for East African region bloc listed firms and the results are statistically significant. Our results are consistency with prior empirical results reported by Abor and Biekpe (2007).Moreover, this results is inconsistency with the research dependence theory (RDT) which suggested that the BOD are key person to bring required resources (e.g. finance etc.). Furthermore, our empirical results indicate a statistically insignificant effects of firm size (SIZ) and statistically significant effects of annual real gross domestic product (GDP) growth (i.e. control variables) on CSD (total debt) at 5\% significance level .The 
coefficients of SIZ and GDP are -0.011 and -1.590 respectively and their p-values are 0.497 and 0.047 for SIZ and GDP respectively. This results suggesting that size of firms in East African regional bloc is negatively related to CSD (total debt) although its effects is statistically insignificant and the country annual real GDP growth is negatively related with CSD (total debt) and its effects is statistically significant, thus firms operating in the East African country with higher GDP will tend to employ a low level of total debt on their capital structure, the possible reason behind this situation is because firms operating in countries with higher GDP will also report good financial performance as a result their retained earnings will also increase and firms will decide to use internal source of financing (retaining earnings) before opt for external sources (total debt) as suggested by the pecking order theory (POT). Table 13 also indicates the firm's industrial effect on CSD (total debt) is statistically significant but the coefficients of industry variable are not reported. Finally, table 13 reported the prob $>$ chi2 of 0.000 at $5 \%$ significance level, suggesting that our model 1c-TDR is statistically significant. Our empirical results are consistent with prior empirical study reported by Abor and Biekpe (2007), therefore, we rejected the hypothesis H1c.

Table 13. Panel Corrected Standard Errors (PCSEs) model results-Model 1c

\begin{tabular}{ccccc}
\hline \multicolumn{5}{c}{ Model 1c: TDR } \\
\hline Variable & Coefficient & Std. Error & t-statistics & Probability \\
\hline Intercept & 0.925 & 0.343 & 2.70 & 0.007 \\
BSCI & -0.024 & 0.011 & -2.15 & 0.031 \\
SIZE & -0.011 & 0.016 & -0.68 & 0.497 \\
GDP & -1.590 & 0.801 & -1.99 & 0.047 \\
Industry Fixed Effects & \multicolumn{5}{c}{ Yes } \\
Number of Observations & \multicolumn{3}{c}{0.170} \\
R-squared & \multicolumn{5}{c}{2023.320} \\
F-statistics & \multicolumn{5}{c}{0.000} \\
Probability (F-statistics) & \multicolumn{5}{c}{} \\
\hline
\end{tabular}

Source: STATA 10 Analysis of Data

\section{Conclusions and Recommendations}

\subsection{Conclusions}

The current research reported the statistically significant negatively effects of board structure characteristics (BSC) on capital structure decision (CSD) for listed firms in East African stock markets, thus firms with better board structure characteristics tend to employ lower levels of debt in their capital structures compared to firms with poorly board structure characteristics.H1a predicts a statistically significant positive relationship between board structure characteristics (BSC) and short term debt ratio (STDR).Hla was rejected in our current research, as the coefficient on board structure characteristics index (BSCI) is negatively and statistically insignificant. This results is consistent with prior empirical results 
reported by Rehman et al (2010).H1b predicts a statistically significant positive relationship between board structure characteristics (BSC) and long term debt ratio (LTDR).H1b was rejected in our current research, as the coefficient on board structure characteristics index (BSCI) is negatively and statistically significant. This result is consistent with prior empirical results reported by Abor and Biekpe (2007). H1c predicts a statistically significant positive relationship between board structure characteristics (BSC) and total debt ratio (TDR).Hlc was rejected in our current research, as the coefficient on board structure characteristics index (BSCI) is negatively and statistically significant. This result is consistent with prior empirical results reported by Abor and Biekpe (2007).

\subsection{Recommendations and Policy Implications}

The current research suggested that capital structure decisions are driven by board structure characteristics. The result indicates that a board structure characteristic (BSC) is significant determinant of capital structure decisions. Furthermore, the BSC has a statistically significant effects on financing decisions, thus firms with better BSC tend to use lower levels of debt compared to firms with poorly BSC. This indicates that listed firms with poor BSC are not attractive to potential investors because of higher cost of capital which has been resulted by the higher agency costs. Therefore listed firms should implement the effective BSC in order to easily access the equity capital markets by weighing up all the costs involved. The East African regional bloc policy makers (Including CMA in Kenya, CMSA in Tanzania, CMA in Uganda, CMA in Rwanda and EASRA), should encouraged the listed firms in the region to keep improving their BSC.

\subsection{Limitations of the Research}

Although the current research empirical results are fairly and important, limitations of the research need to be identified. First, our current research used East African listed firms, therefore our empirical results might not be generalized to small and non-listed firms. Secondly, the development of capital market in the East African regional bloc is not at the same level. Kenya is more advanced compared to other East African Partner States (i.e. Tanzania, Uganda, Rwanda, Burundi and South Sudan), so this might affect the level of board structure characteristics compliance among the listed firms in the East African regional bloc but also the financing behavior of the listed firms among the East African regional bloc. Despite the limitations identified above, the quality of this current research was not compromised. The current research has made contribution to the existing corporate governance and capital structure literature by filling the gap, especially in developing economies and more specifically to the East African region bloc which has not been investigated.

\subsection{Suggestions for Further Research}

The current research used East African listed firm to assess the overall effects of board structure characteristics on capital structure decisions. The future study may include both listed and unlisted firms in the East African regional bloc in order to improve the results of current study. Finally using only quantitative research methodology to perform study analysis 
may affect the ability to interpret the empirical results, the future study may use both qualitative and quantitative methodologies in order to help to overcome current research problem. The future study may use other sources of information such as reports of analyst in order to complement firms' annual reports, this will help increase the data source.

\section{References}

Abor, J., \& Biekpe, N. (2007). Corporate governance, ownership structure and performance of SMEs in Ghana: Implications of financing opportunities. Corporate Governance, 7(3), 288-300. https://doi.org/10.1108/14720700710756562

Adams, R.B. (2012). Foreword to special issue: Governance, policy and the crisis. $\begin{array}{llll}\text { International Review } & \text { of } & \text { Finance, } & \text { 12(1), }\end{array}$ https://doi.org/10.1111/j.1468-2443.2012.01150.x

Akbari, A., \& Rahmani, S. (2013). Does corporate governance and ownership structure influence capital structure? World of Sciences Journal, 1(17), 72-85.

Al-Najjar, B., \& Hussainey, K. (2011). Revisiting the capital-structure puzzle: UK evidence. Journal of Risk Finance, 12(4), 329-338. https://doi.org/10.1108/15265941111158505

Babalola, Y. A., \& Yinusa, O. G. (2012). The impact of corporate governance on capital structure decisions of Nigerians firms. Research Journal in Organizational Psychology and Educational Studies, 1(2), 121-128.

Barney, J.B. (1991). Firm resources and sustained competitive advantage. Journal of Management, 17(1), 99-120. https://doi.org/10.1177/014920639101700108

Becht, M., Bolton, P., \& Rosell, A. (2004). Corporate governance and control. National Bureau of Economic Research, Cambridge.

Berger, P. G., Ofek, E., \& Yermack, D. L. (1997). Managerial entrenchment and capital structure decisions. Journal of Finance, 52(4), 1411-1438. https://doi.org/10.1111/j.1540-6261.1997.tb01115.x

Bevan, A., \& Danbolt, J. (2002). Capital structure and its determinants in the United Kingdom - a decomposition analysis. Applied Financial Economics, 20(3), 159-170. https://doi.org/10.1080/09603100110090073

Black, B. S., Jang, H., \& Kim, W. (2006). Does Corporate Governance Predict Firms' Market Values? Journal of Law, Economics and Organization, 22.

Brenni, P (2014). Corporate governance and capital structure decisions of UK listed Real Estate companies. Research Journal of Finance and Accounting, 5(1), 42-54.

Breusch, T.S. (1978). Testing for autocorrelation in dynamic linier models. Australian Economic Papers, 17, 334-355. https://doi.org/10.1111/j.1467-8454.1978.tb00635.x

Capital Market Authority in Kenya. Retrieved $15^{\text {th }}$ December 2015 from 
http://www.cma.or.ke

Capital Market and Security Authority in Tanzania. Retrieved 22 $2^{\text {th }}$ November 2015 from http://www.cmsa.go.tz

Capital Market Authority in Uganda. Retrieved $4^{\text {th }}$ November 2015 from http://www.cmauganda.co.ug

Chitiavi, M. S., Musiega, M. G., Alala, O. B., Musiega, D and Maokomba, C. O (2013). Capital structure and corporate governance practices-Evidence from listed non-financial firms on Nairobi securities exchange, Kenya. IOSR Journal of Business and Management, 10(2), 08-16. https://doi.org/10.9790/487X-1020816

Daily, C. M, Dalton, D. R., \& Cannella, A. A. (2003). Corporate Governance: Decades of Dialogue and Data. The Academy of Management Review, 28, 371-82.

Dalton, D. R, Daily, C. M., \& Certon, S. T., \& Roengpitya, R. (2003). Meta-analyses of financial performance and equity: Fusion or Confusion? Academy of Management Journal, 28, 13-26. https://doi.org/10.2307/30040673

Dar es Salaam Stock Exchange (DSE) in Tanzania, Retrieved from: http://www.dse.co.tz

Douma, S., George, R., \& Kabir, R. (2006). Foreign and domestic ownership, business groups and firm performance: Evidence from a large emerging market. Strategic Management Journal, 27, 637-657. https://doi.org/10.1002/smj.535

East African Community (EAC), Retrieved from: http://www.eac.int

Erkens, D., Hung, M., \& Matos, P. (2012). Corporate governance in the 2007-2008 financial crisis: Evidence from financial institutions worldwide. Journal of Corporate Finance, 18, 389-411. https://doi.org/10.1016/j.jcorpfin.2012.01.005

Greenglass, E., Antonides, G., Christandl, F., Foster, G., Katter, J.K., Kaufman, B.E., \& Lea, S.E. (2014). The financial crisis and its effects: Perspectives from economics and psychology. Journal of Behavioral and Experimental Economics, 50, 10-12. https://doi.org/10.1016/j.socec.2014.01.004

Gujarati, D.N. (2003). Basic Econometrics (4th Edition). McGraw-Hill Companies, New York, USA.

Hillman, A.J., Withers, M.C., \& Collins, B.J. (2009). Resource dependence theory: A review. Journal of Management, 35(6), 1404-1427. https://doi.org/10.1177/0149206309343469

Hossain, I., \& Hossain, A. (2015). Determinants of capital structure and testing of theories: A study on the listed manufacturing companies in Bangladesh. International Journal of Economics and Finance, 7(4), 176-190. https://doi.org/10.5539/ijef.v7n4p176

Hove, M. (1986). Accounting practices in developing countries: Colonialism's legacy of inappropriate technologies. International Journal of Accounting Education and Research, 22(1), 81-100. 
Hove, M. (1990). The Anglo-American influence on international accounting standards: The case of the disclosure standards of the international accounting standards committee. Research in Third World Accounting, 1, 55-66.

Hussainey, K., \& Aljifri, K. (2007). Corporate governance mechanism and capital structure in UAE. Journal of Applied Accounting Research, 13(2), 145-160. https://doi.org/10.1108/09675421211254849

International Monetary Fund (IMF), Retrieved from http://www.imf.org

Jensen, M. C., \& Meckling, H. W. (1976). Theory of the firm: Managerial behavior, agency cost and ownership structure. Journal of Financial Economics Review, 3, 305-360. https://doi.org/10.1016/0304-405X(76)90026-X

Jensen, M.C. (1993). The modern industrial revolution, exit, and the failure of internal control system. Journal of Finance, 48(3), 831-880. https://doi.org/10.1111/j.1540-6261.1993.tb04022.x

Johnson, S. (1999). Does investor protection matter? Evidence from Germany's Neuer Market. MIT Press, Cambridge, MA.

Kajananthan, R (2012). Effect of corporate governance on capital structure: Case of Sri Lank listed manufacturing companies. Journal of Arts, Science and Commerce, 3(4), 63-71.

Klein, A. (2002). Audit committee, board of director characteristics, and earnings management. Journal of Accounting and Economics, 33(3), 375-400. https://doi.org/10.1016/S0165-4101(02)00059-9

Kmeta, J. (1997). Elements of Econometrics (2 ${ }^{\text {nd }}$ Edition). Ann Arbor: University of Michigan Press. https://doi.org/10.3998/mpub.15701

Krejcie, R.V., \& Morgan, D.W (1970). Determining sample size for research activities. Educational and Psychological Measurement, 30, 607-610. https://doi.org/10.1177/001316447003000308

Levin, A., Lin, C.F., \& Chu, C.S.J. (2002). Unit root test in panel data: Asymptotic and finite-sample properties. Journal of Econometrics, 108, 1-24. https://doi.org/10.1016/S0304-4076(01)00098-7

Lewis-Beck, M.S. (1993). Applied Regression: An Introduction to Regression Analysis. Singapore: Sara Miller McCune, Sage Publications Inc.

Masnoon, M., \& Rauf, M. (2014). The impact of corporate governance on capital structure-A study of KSE listed firms. Global Management Journal for Academic and Corporate Studies, 3(1), 94-110.

Mehran, H. (1992). Executive incentive plans, corporate control, and capital structure. Journal of Financial and Quantitative Analysis, 27(4), 539-560. https://doi.org/10.2307/2331139 
Monda, B., \& Giorgino, M. (2013). Corporate governance and shareholder value in listed firms: An empirical analysis in five countries (France, Italy, Japan, UK and USA). DIG, Politecnico di Milano, MPRA Paper No.45429.

Mwambuli, E. L. (2015). What determine corporate capital structure in developing economies? Evidence from East African stock markets. Research Journal of Finance and Accounting, 6(12), 221-239.

Mwambuli, E. L. (2016a). Does corporate capital structure influence corporate financial performance in developing economies? Evidence from East African stock markets. International Finance and Banking, 3(1), 97-123. https://doi.org/10.5296/ifb.v3i1.9357

Mwambuli, E. L. (2016b). The effects of board structure characteristics on corporate financial performance in developing economies: Evidence from East African stock markets. European Journal of Business and Management, 8(30), 126-138.

Mwangi, L., Makau, M., \& Kosimbei, G. (2014). Relationship between capital structure and performance of non-financial companies listed in Nairobi securities exchange, Kenya. Global Journal of Contemporary Research in Accounting, Auditing and Business Ethics (GJCRA), 1(2), 72-90.

Nairobi Securities Exchange (NSE) in Kenya, Retrieve from http://www.nse.co.ke

Ngan, T. (2013). Board characteristics and capital structure: A study of listed firms in Hochiminh city stock exchange. BBA Thesis, School of Business, Vietnam National University, Vietnam.

Osiris DataStream, Retrieve from http://www.bvdinfo.com

Pfeffer, J. (1972). Size and composition of corporate boards of directors: The organization and its environment. Administrative Science Quarterly, 17(2), 218-228. https://doi.org/10.2307/2393956

Pfeffer, J., \& G.J. Salancik. (1978). The external control of organizations: A resource dependence perspective. New York: Harper \& Row.

Priya, K., \& Nimalathasan, B. (2013). Board characteristics and capital structure: A case study of selected hotels and restaurants in Sri Lanka. International Journal of Advanced Research in Management and Social Science, 2(12), 21-33.

Rant, U.O. (2013). The effects of board size and CEO duality on firms' capital structure: A study of selected listed firms in Nigeria. Asian Economic and Financial Review, 3(8), 1033-1043.

Rehman, M., Rehman, R., \& Raoof, A. (2010). Does corporate governance lead to a change in the capital structure? American Journal of Social and Management Sciences, 1(2), 191-195. https://doi.org/10.5251/ajsms.2010.1.2.191.195

Rwanda Stock Exchange (RSE) in Rwanda, Retrieve from http://www.rse.rw 
Shapiro, S.S., \& Wilk, M.B. (1965). An analysis for variance test for normality (complete samples). Biometrika, 52(3-4), 591-611. https://doi.org/10.1093/biomet/52.3-4.591

Sheikh, N.A., \& Wang, Z. (2012). Effects of corporate governance on capital structure: Empirical evidence from Pakistan. Corporate Governance, 12(5), 629-641. https://doi.org/10.1108/14720701211275569

Uganda Securities Exchange (USE) in Uganda, Retrieve from http://www.use.or.ug

Vinasithamby, S. (2014). Determinants of capital structure-A study of listed banks finance and insurance companies in Colombo stock exchange in Sri Lanka. International Journal of Economics, Commerce and Management, 11, 1-18.

Wang, L., Kuo, H., \& Liu, H (2012). Corporate governance and capital structure: Evidence from Taiwan SMEs. Review of Economics and Finance, 2, 43-58. https://doi.org/10.1016/j.iref.2011.11.007

Wen, Y., Rwegasira, K., \& Bilderbeek, J (2002). Corporate governance and capital structure decisions of the Chinese listed firms. Corporate Governance: An International Review, 10(2), 75-83. https://doi.org/10.1111/1467-8683.00271

World Bank (WB), Retrieved from: http://www.worldbank.org

World Bank. (2000). Corporate governance: A framework for Implementation. A World Bank Country Study, Washington.

Yaseen, H., \& Amarneh, A. (2013). Corporate governance and capital Leverage: Evidence from Jordanian stock markets. Research Journal of Finance and Accounting, 4(19), 29-35.

\section{Notes}

Note 1. The EAC was established in 2000 by Kenya, Tanzania and Uganda; Rwanda and Burundi joined in 2007 and later in 2016 South Sudan joined the EAC.

Note 2. The Communique of the $13^{\text {th }}$ Summit of EAC Heads of State itemized receipt of applications from Sudan, South Sudan and Somalia.

Note 3. The Industrial groupings of firm are based on NSE's industrial classification. Therefore, listed firms on DSE and USE were grouped in similar basis.

Note 4. Accessories and Automobile industry has been considered as base industry.

\section{Copyright Disclaimer}

Copyright for this article is retained by the author(s), with first publication rights granted to the journal.

This is an open-access article distributed under the terms and conditions of the Creative Commons Attribution license (http://creativecommons.org/licenses/by/3.0/). 